\title{
PUBLIC HEALTH AND HEALTH CARE
}

\author{
UDC 614.3:639.2:579.67
}

\section{Microbiological safety of marine products (seafood)}

\author{
S. A. Lopatin ${ }^{1}$, V. V.Zakrevskii ${ }^{2}$, E. I. Yuvanen ${ }^{3}$ \\ ${ }^{1}$ Institute of the Military Medicine, \\ 4, Lesoparkovaya ul., St. Petersburg, 195043, Russian Federation \\ ${ }^{2}$ North-Western State Medical University named after I. I. Mechnikov, \\ 41, Kirochnaya ul., St. Petersburg, 191015, Russian Federation \\ ${ }^{3}$ Russian College of Traditional Culture, \\ 51, Dalnevostochny pr., St. Petersburg, 193230, Russian Federation
}

For citation: Lopatin S. A., Zakrevskii V. V., Yuvanen E.I. Microbiological safety of marine products (seafood). Vestnik of Saint Petersburg University. Medicine, 2020, vol. 15, issue 2, pp. 134-141.

https://doi.org/10.21638/spbu11.2020.205

Recently more and more evidence appears, proving that seafood consumers should be referred to risk group in which outbreaks of viral food poisoning and foodborne infectious diseases occurs, transmitted by food route. There are several reasons to refer seafood to a category of epidemiologically non-safe products: high microbial pollution of adjacent seas with sewage waters; many non-fish hydrocoles are natural filter feeding animals, which are infected by viruses in the process of vital activity, passing through their organism water and food particles; sufficient viruses stability in external environment, enabling them to remain intact outside of host organism during of prolong time interval. Total rate of viral material detection in seafood samples may reach $\sim 10 \%$. The authors by means of expertise determined virological effect of thermal seafood treatment used in housekeeping conditions and at public catering establishments for preparing mostly widespread dishes. In this paper a conclusion is made, that the use of seafood for preparing dishes, which technology does not consider sufficiently efficient in respect to viruses thermal treatment, shall include preliminary virologic survey of stuff for excluding viral pathogens and for provision safety of the corresponding food products.

Keywords: seafood, enteroviruses, norwalk-like viruses, hepatitis A viruses.

\section{Introduction}

It is used to call seafood those products that are worked out from non-fish aquatic organisms. World's oceans and seas inhabited by over 90 thousands kinds of non-fish objects, including algae. Seafood includes: crustaceans (crabs, prawns, crawfish, crayfish), squids (calamaries, octopuses), bivalved mollusks (oysters, mussels, scallops), and also algae (laminaria or sea girdle). Main marketable objects are mollusks and crustaceans,

(c) Санкт-Петербургский государственный университет, 2020 
which are by catch volume constitutes approximately 65 and $33 \%$ correspondingly from the total non-fish seafood volume. Some seafood are bring up in special ponds with application stimulants, colouring agents and antibiotics.

In 2019 department of fishery and aquaculture at Food and Agricultural Organization (FAO)/World Health Organization (WHO) pointed out exclusive role of water resources for food production due to its considerable diversity: over 30 thousands of fish kinds, 52 thousands of molluscs kinds and 64 thousands crustaceas ${ }^{1}$. In 1950, when FAO/ wHO begun to publish corresponding statistics, total mass of consumed razor-fishes was estimated in 1,007,419 tonnes. In 2000 this value constitutes 10,293,607 tonnes, and in $2010-14,616,172$ tonnes. Consumption of mussels in 2010 reached 1,901,314 tonnes, oysters - 4,592,529 tonnes, cristaes - 2,567,981 tonnes. In China consumption of razorfishes for 30 years increased in 400 times. At special enterprises of artificial propagation mussels and oysters are grown up. Most successfully such enterprises are developed in USA, Japan, France, Spain and Italy.

\section{Aim of investigation}

Analysis of epidemiological seafood role in transmitting enteroviruses to human via food tract and justification of preventive measures importance.

\section{Materials and investigation methods}

Literature data analysis concerning volumes of seafood sales, kick-ups of viral infections with food transfer mechanism, expert evaluation of virological action produced by thermal treatment on seafood.

\section{Results of investigation}

Russia possesses considerable water-biological resources. So, its volume only in FarEastern basin constitutes 26 million tonnes. Capture wealth of Okhotsk Sea, Sea of Japan and Bering Sea enable to gain for country's population sufficient amount of fish, crustaceans, molluscs, algae. Diversity of marketable objects may be explained by water saltiness, by worm and cold streams, by sea floor, by temperature regime. Water in Japan Sea at summer months rises up to +23 degrees, that is rather favorable condition for reproduction and growth of many invertebrate marketable sea animals.

In 2017 molluscs export and import in Russia constituted 21.6 and 22.0 thousands tonnes correspondingly ${ }^{2}$. In trade pattern of affiliated retailers of Russia contribution of fish-food occupies $15 \%$, and contribution of seafood - 16\%. In Moscow supermarkets net volume of prawns sales, crabs, crabmeat sticks, crawfish, lobsters and other fresh frozen seafood exceeds $20 \%$.

Due to a special chemical composition seafood is a valuable foodstuff [1]. They are widely used in dishes of Japan, Spanish, French, Italian and so called "Mediterranean" cuisines. The most numerous, budgetary, eligible, useful and tasty marketable cuttlefishes

${ }^{1}$ FAO Committee on Fisheries. Report on the tenth session of the Subcommittee on Aquaculture. Trondheim, Norway, 23-27 August 2019. FAO Fisheries and Aquaculture Report Series, Report no. 1287. Rome. 2020. https://doi.org/10.4060/ca7417ru. (In Russian)

${ }^{2}$ Russian statistical yearbook. 2018: Statistical collection. Moscow, Rosstat Publ., 2018, 694 p. (In Russian) 
of Far East are calamaries. More rarely you can meet on sake the nearest relatives of calamaries - octopus and cuttlefish. At Primorye's shelf there are dwells a giant octopus, some specients of which grows up to 5 meters long and reaches $60 \mathrm{~kg}$ by weight. Giant octopuses grow very swiftly, gaining daily in weight up to $2 \%$ from the weight of their body, and live from 3 to 5 years. Catfishes are rich in vitamins, in potassium, sodium, manganese, selenium, phosphorus, zink, fatty acids omega- 3 and omega- 6 and actually in all amino acids, necessary for human organism.

From the point of view of ecology, some seafood possess another useful property, which is actual for the regions with highly contaminated environment. Unfortunately, these include also Russia, in which water bodies annually discharged up to $52 \mathrm{~km}^{3}$ of waste waters. Among them full decontamination does not pass $12.3 \%$, and from waste waters, which pass decontamination, less than a half are decontaminated in accordance with regulatory requirements [2]. That is why many water bodies are in unsatisfactory condition. In a number of regions bivalved mollusks participate in their media decontamination, playing the role of natural filter-feeding animals. It was found out, for example, that Blak Sea one $50 \mathrm{~mm}$ mussel daily filters out out $44.5 \mathrm{l}$ of water, and mussels, dwelling at the surface of South Mole of Sevastyanovskaya bay (its area constitutes $339600 \mathrm{~m}^{2}$ ), each day filter out 7390 thousands $\mathrm{m}^{3}[3]$.

But environment protecting function of some sea's thalassophilus have a negative feature. Above mentioned bivalved mollusks, passing through their branchiae a sagan volume of water, filter out and consumes not only food particles, but also microorganisms, including viruses, heavy metals, which stay in mollusks tissues and accumulate in their liver [4]. So, after feeding mussels by suspension, highly contaminated by viruses, the last were detected in mussels 1 hour later, and maximal level of infection was observed 6 hours later [5]. As a result number of viruses in mussel organism may considerably exceed corresponding indexes of the same viruses, located in marine environment or in sea-floor sediments. For example, at one of the sites of New Zealand sea cost at the region of New Plymouth near outlet of wast waters discharge the number of enteroviruses in green-limbic mussels in 1000-10000 times higher, than ib sea-floor sediments [6]. In Northern part of Adriatic Sea during a year investigate occurrence of different virus strains of hepatite A (HAV) and noroviruses (NoVs) in bivalved mollusks, in Mediterranean mussels as well, in oysters and cristae [7]. Viruses from 235 samples were detected in $52(22 \%)$ samples, besides $6 \%$ of samples gave positive result on HAV presence, $14 \%$ - NoVs and $2 \%$ - on both viruse groups simultaneously. Viruses occurrence in mollusks possesses whole-year character. In Western part Mediterranean Sea at cost line of Spain HAV was detected in $24 \%$ of tested mollusks, adenoviruses of human - in $47 \%$, enteroviruses - in $19 \%$ [8]. In Black Sea basin, due to discharge of uncontaminated waste waters, almost one-third fraction of Black Sea mussels contain pathogenic viruses and bacteria [9].

Therewith it is not the matter of accidental, episodic virus detection in mussels, but of regular registration pathogenic for human viruses in mollusks actually in all the regions of the World. Occurrence of enteroviruses in mussels depends upon it circulation in human community, and also upon many other biotic and abiotic factors. It is important, that infected by pathogenic for human viruses mussels may transmit them further though nutritional chain by eating them predator, for example, by crabs, which as a result become dangerous for the health of humans. And, at last, a role of viruses vector may play birds, in which dietary intake infected mollusks got in. With birds excrements viruses may get 
in new water basins regions, where till now natural nidus of infection was absent [5]. The author pointed out, that enteroviruses detection in sea water, which by bacteriological indexes corresponds recent standards, shows, that these standards does not reflect enteroviruses occurrence in mussels from the same sites, where water was sampled for analysis.

Viruses, entering into human organism with contaminated food, include wide range of enteric pathogen, such as noroviruses, rotaviruses (RV), enteroviruses (EV), intestinal adenoviruses (AV), Norfolk-viruses (NV), viruses of hepatitis A (VHA) and E (VHE) [10]. Viral contamination was detected of seafood samples, fresh vegetables and fruits, multi-component dishes, consumed without preliminary thermal treatment. Total rate of viral material detection is seafood samples may reach $\sim 10 \%$.

Leading role among enteric pathogen belong to noroviruses, which due to their high contagiosity, low infective dose and ability to persist in external environment are recognized as a new emergent causative agent of diseases transmitted though food tract, arising more number of outbreaks, than all the other known bacterial, viral and protozoal causative agents taken together. In USA it is considered, that noroviruses are the main reason of viral gastroenteritis, meanwhile morbidity reaches 23 millions cases annually, and in total structure of alimentary infections ratio of noroviral kick-ups constitutes 30-50\% [11]. Earlier (in 1978) food poisoning outbreaks occurred in Australia, when 2 thousands humans suffered due to eating contaminated oysters [12]. Noroviral outbursts are often connected with eating of foodstuff, containing infected in aquatoriums mollusks and other seafood [13].

Norfolk-virus (NV) - the second by relevance among the known enteroviruses, by which human being is infected through food, particularly from sea mollusks, and the same virus is the main causative non-bacterial gastroenteritis. One of the gastroenteritis outbursts in Australia took place in 1990, when as a result of heavy rains non decontaminated waste waters penetrated into the zone of collecting mollusks [14]. Boxman et al. in course of mollusks investigating just after their delivering into the country discovered, that $12.5 \%$ of samples oysters and $38.5 \%$ mussels were noroviruses carriers [15].

Also actual food poisoning outbursts, caused by hepatitis A virus. So, in 1988 in Shanghai (China) massive hepatitis A outburst occurred with total number of sufferers over 300 thousands humans. Factor of viral infection transfer were crude mussels - clams [16]. In Sweden in 1955 by hepatitis A were infected 629 humans, which were related with using in meal crude oysters. In USA outburst of infective hepatitis affected over 600 people, and the source of people infecting were oysters, which before sales were hold in a bay, which waters was contaminated by faeces. In Italy main factor which caused in $62 \%$ cases hepatitis A in humans, was eating mollusks, used without corresponding food preparation [17]. At the beginning of XXI century researches from Rome detected hepatitis A virus not only in artificially raised in Italy mollusks (mussels, oysters, tapes), but also in thous, which were supplied in this country from other regions of Mediterranean Sea [18].

Main food objects, in which rotoviruses (affecting mainly children less than 2 years old, elderly and immune - compromised groups of population) are detected, are mussels, oysters, vegetable salads, berries and fruits [19].

High frequency of mollusks contamination by adenoviruses was detected in $47 \%$ of mussels and oysters samples in investigation carried out in Spain, alongside with causative agents of hepatitis A (in $24 \%$ samples) and other enteroviruses (in 19\% samples) [20]. It was reported about adenoviruses detection in mussels, habited in Skagerrack bay of coastal waters of Sweden, in western part of Mediterranean Sea near Spain, in Ligurian 
Sea in coastal region of Italy, as well as in Black Sea [5]. Due to insufficient data concerning adenoviral food outbursts, their presence in seafood usually are considered s indicator of contamination by other enteroviruses. High frequency of adenoviruses detection is associated with their resistance to adverse action of external environment, enabling them to remain integrity outside of host organism during prolonged time intervals.

Significance of seafood as a source of human contamination by many pathogenic viruses is very high and require further comprehensive investigation. But in discussion of seafood role in circulation one or another virus kind in marine communities (thalassium) it is necessary to use information about their survivability in external environment and resistance to thermal influence.

It is known, that viruses, infecting human, including hepatitis a virus, does not infect mollusks and does not replicate in them, but remains integrity in their alimentary tract rather prolong time intervals, remaining infected state during several days and even weeks. By numerous experiments it was determined, that hepatitis A virus is more resistive to heating, than most other enteroviruses, highle resistive to drying and may survive for a long time in sea water [5]. Croci et al. tried to determine, what will happen with hepatitis A viruses, if subject mussels to high temperature action [21]. It is known that high temperatures cause coagulation and rupture of viruses protein layer, but environment, where viruses are detected, influence on their sensitivity to thermal inactivation, because their protein coat protect viruses from heat action. That is why in steam treated mussels during 5 minutes after valves opening it is possible to detect HAV, as well as rotaviruses [22]. But recommendations of foreign specialists on mollusks decontamination from viruses stated that it is necessary to subject them to high temperature action the way, when during 1.5 minutes internal meat temperature was hold at $90^{\circ} \mathrm{C}$.

Table below contains determined experimentally efficiency of thermal treatment of some seafood in the process of dishes preparation in domestic and forign cookery. At estimation of their contamination efficiency (virucidal action) it was considered, that for complete viruses inactivation it is necessary to heat foodstuff over $60^{\circ} \mathrm{C}$ for over 10 minutes.

Thereby, anti-viral effect is not reached, if seafood dish preparation procedure does not include rather tough and prolong thermal treatment. In this paper a conclusion is made, the the use of seafood for preparing dishes, which technology does not consider sufficiently efficient in respect to viruses thermal treatment, shall include preliminary virologic survey of stuff for excluding viral pathogens and for provision safety of the corresponding food products.

A group of personnel risk, nearly related with sea products, also includes tourists with high probability of infection and parasitic diseases development with nutritional nature [1; 24]. According to data of Federal Tourism Agency, for last two years touristic market of Russia had seriously changed (off-site tourist trips were decreased on $20 \%$ ), but remained at high level: 34 million off-site trips a year ${ }^{3}$. But not all tourists know, international trips, especially recently popular into exotic countries, may present a serious danger to their health. Unfortunately, representatives of travel agencies do not often warn travelers about precinctive for different infectious diseases, including enteric infection. As a result, only in 1980-1990 50\% of foreign travelers, who visited developing countries, had problems with their health, and $8 \%$ were hospitalized, $1.1 \%$ lost after return their workability and $0.3 \%$

${ }^{3}$ Federal Agency for Tourism. Indicators of the departure of Russian citizens abroad Access mode. Available at: https://www.russiatourism.ru (accessed: 20.09.2020). (In Russian) 
patients were hospitalized during their trip or immediately after terurn at home, 1 person of 100000 travelers perished [25]. Outburst of hepatitis E, raised among the passenger of cruise liner in Great Britain after the cruise, which continued from January to March 2008, was described. $25 \%$ of serologically inspected persons possess hepatitis E viral markers. As a risk factor was consumed by passengers dishes prepared from oysters and crabs [26].

Table. Virucidal effect of seafood thermal treatment

\begin{tabular}{|c|c|c|c|}
\hline \multirow{2}{*}{ Seafood } & \multicolumn{3}{|c|}{ Dishes from seafood } \\
\hline & Effect is absent & Partial effect & Complete effect \\
\hline Mussels $^{* 1}$ & $\begin{array}{l}\text { Salad with mussels } \\
\text { (without thermal treatment) }\end{array}$ & $\begin{array}{l}\text { Mussels curry (stewing } \\
\text { from } 7 \text { to } 8 \text { minutes) }\end{array}$ & $\begin{array}{l}\text { Pilau with mussels (frying and } \\
\text { boiling from } 25 \text { to } 30 \text { minutes) }\end{array}$ \\
\hline Scallops & $\begin{array}{l}\text { Scallops with citric dressing } \\
\text { and greens (without thermal } \\
\text { treatment) }\end{array}$ & $\begin{array}{l}\text { Shish kebabs from sea } \\
\text { scallops (after marinading is } \\
\text { prepared at barbecue or in } \\
\text { oven for } 5 \text { minutes) }\end{array}$ & $\begin{array}{l}\text { Stewed scallops in cow butter } \\
\text { with herbes de Provence (for } \\
10 \text { minutes) }\end{array}$ \\
\hline Oysters & $\begin{array}{l}\text { Oysters prepared as in } \\
\text { Russia (heating up to } \\
3 \text { minutes) }\end{array}$ & $\begin{array}{l}\text { Oysters at barbecue (baking } \\
\text { up to } 5 \text { minutes) }\end{array}$ & \\
\hline Crawfishes & & $\begin{array}{l}\text { Salad with crawfish (boiling } \\
\text { up to } 5 \text { minutes) }\end{array}$ & $\begin{array}{l}\text { Crawfich at frying pan with } \\
\text { garlic (frying and stewing up } \\
\text { to } 30 \text { minutes) }\end{array}$ \\
\hline Mussels $^{\star 2}$ & & $\begin{array}{l}\text { Boiled mussels with citric } \\
\text { juice in microwave oven } \\
\text { (from } 1 \text { to } 2 \text { minutes) }\end{array}$ & $\begin{array}{l}\text { Paste with mussels in cow } \\
\text { butter sauce (frying, stewing } \\
\text { for } 10 \text { minutes) }\end{array}$ \\
\hline Lobsters & & & $\begin{array}{l}\text { Lobsters with vegetables } \\
\text { (boiling, stewing for } \\
15 \text { minutes) } \\
\end{array}$ \\
\hline Crayfish & & & $\begin{array}{l}\text { Crayfish, baked with potatos } \\
\text { (boiling, baking from } 5 \text { to } \\
7 \text { minutes) }\end{array}$ \\
\hline Crabs & & & $\begin{array}{l}\text { Salad with cucumber and crab } \\
\text { (boiling in sea water from } 10 \text { to } \\
15 \text { minutes (small sized), from } \\
30 \text { to } 40 \text { minutes large sized } \\
\end{array}$ \\
\hline Calamaries & & $\begin{array}{l}\text { Heh from calamars (pickling } \\
\text { for } 10-15 \text { minutes) }\end{array}$ & $\begin{array}{l}\text { Calamaries with rice and } \\
\text { vegetables (boiling and baking } \\
\text { for } 10 \text { minutes) }\end{array}$ \\
\hline Octopuses & $\begin{array}{l}\text { Salad with octopuses and } \\
\text { potato (without thermal } \\
\text { treatment) }\end{array}$ & $\begin{array}{l}\text { Fried octopus with garlic } \\
\text { and tomato (frying for } \\
2 \text { minutes) }\end{array}$ & $\begin{array}{l}\text { Rizotto with octopus (boiling, } \\
\text { stewing for } 45 \text { minutes) }\end{array}$ \\
\hline $\begin{array}{l}\text { Cucumaria } \\
\text { (trepang) }\end{array}$ & $\begin{array}{l}\text { Trepang with soybean- } \\
\text { vinegar sauce (without } \\
\text { thermal treatment) }\end{array}$ & & $\begin{array}{l}\text { Skobliaka from trepang } \\
\text { (boiling from } 2 \text { to } 3 \text { hours) }\end{array}$ \\
\hline
\end{tabular}

Note: ${ }^{* 1}$ - At home mussels are subjected to thermal treatment till they open their valves - usually it takes at $70^{\circ} \mathrm{C}$ from 45 to 50 seconds [23]. Therein during first several minutes of cooking internal temperature of the product at the average on $7-8^{\circ} \mathrm{C}$ lower than external. Such slightly treated mussels together with their viscuses prefer to eat all over the world.

${ }^{*} 2$ - In Japan and China shrimp was renamed into peony or botan, and in these countries cooking method of botan is used, in which invertebrate remains alive. Eating of such a dish require specially careful jaw operation of seafood lover to exclude possibility of swallowed shrimp's leg moving to injure gullet and stomach. 
Outbursts of viral infections among foreign tourists were related with eating dishes prepared from different kinds of stuff (including seafood), contaminated by causative agents (rotoviruses, noroviruses, hepatitis E viruses), highly resistive to influence of external environment factors, including resistance to heating, used in the process of cooking. It is not required to prove a well known statement, that viral contamination like a bacterial one does not change organoleptical properties, and food handlers and consumers have no doubt in stuff quality and of cooked from them dishes.

Focusing attention on seafood example on the necessity to carry more strict and prolonged thermal treating of foodstuff do not exclude high probability of dishes taste impairment (including transformation of meat category from soft into coarse meat), that should be considered at planning applicable stuff list, menu preparation and food-intake organization at the objects of food industry.

\section{Conclusion}

Potential hazard of viral infection transmission though foodstuffs deserves careful attention in connection with accommodation of new data about etiology and pathogenesis of viral intestinal diseases, development of highly informative methodological approaches to pathogenic viruses indication in foodstuffs and in environmental objects. Application of modern methods of alimentary viruses detection, creation on their base monitoring system (production, veterinary and sanitary), including the order and investigations organization, acquisition and exchange of information with competent organizations in the real time mode, enabling considerably increase efficiency of preventive measures, directed to prevent viral infection outbursts with food tract transmission, to decrease risk of cross contamination at food production facilities, to decrease probability of usage contaminated by viral pathogens stuff in production process and to increase safety of respective products.

\section{References}

1. Lopatin S. A., Yuvanen E. I. Problems of seafood consumption in the context of the current ecological situation and the growth of the volume of world tourism. Problems of the modern economy, 2018, no. 1 (65), pp. 166-169. (In Russian)

2. Nedachin A.E., Dmitrieva R.A., Doskina T. V., Dolgin V.A., Chulanov V.P., Pimenov N. N. Wastewater as a reservoir of pathogens of intestinal viral infections. Hygiene and sanitation, 2015, no. 7, pp. 37-40. (In Russian)

3. Kozlova O.V. Calculation of the filtration activity of the Black Sea mussel population living on the pier of the Sevastopol Bay. Ecology of the Sea, 2004, iss. 66, pp. 64-66. (In Russian)

4. Seafood. Available at: https://ru.wikipedia.org/wiki (accessed: 20.09.2020). (In Russian)

5. Gaevskaya A.V. Parasites, diseases and pests of mussels (Mytilus, Mytilidae). IV. Viruses, Sevastopol, ECOSI-Hydrophysics Publ., 2007. 96 p. (In Russian)

6. Lewis G., Loutit M.W., Austin F.J. Enteroviruses in mussels and marine sediments and depuration of naturally accumulated viruses by green lipped mussels (Perna canaliculus). N.Z. J. Mar. Freshwater Res., 1986, vol. 20, pp. 431-437.

7. Croci L., Losio M.N., Suffredini E., Pavoni E., Pasquale S.-D., Fallacara F., Arcangeli G. Assessment of human enteric viruses in shellfish from the northern Adriatic Sea. Intern. J. Food Microbiol., 2007, vol. 114 (2), pp. 252-257.

8. Muniain-Mujika I., Calvo M., Lucena F., Girones R. Comparative analysis of viral pathogens and potential indicators in shellfish. Intern. J. Food Microbiol., 2003, vol. 83 (1), pp. 75-85. 
9. Rudneva I. I., Shevchenko N.F., Zalevskaya I. N., Zherko N. V. Biomonitoring of coastal waters of the Black Sea. Water resources, 2005, iss. 32, no. 2, pp. 238-246. (In Russian)

10. Amvroseva T.V., Kazinets N.V., Poklonskaya N. V., Lozyuk S.K., Shilova Yu.A., Koltunova Yu.B. Modern approaches and methods for solving the problem of studying viral contamination of food products and assessing its safety for health. Food industry: science and technology, 2019, vol. 12, no. 3 (45), pp. 68-73. (In Russian)

11. Mead P. S., Slutsker L., Dietz V., McCaig L. F., Bresee J. S., Shapiro C., Griffin P. M., Tauxe R. V. Foodrelated illness and death in the United States. Emerg. Infect. Dis., 1999, vol. 5 (5), pp. 607-625.

12. Murphy A. M., Grohmann G. S., Christopher P.J. An Australia-wide out-break of gastroenteritis from oysters caused by Norwalk virus. Med. J. Austr., 1979, vol. 2 (7), pp. 329-333.

13. Maunula L., Miettinen I.T., von Bonsdorff C.H. Norovirus outbreaks from drinking water. Emerg. Infect. Dis., 2005, vol. 11 (11), pp. 1716-1721.

14. Bird P., Kraa E. Overview of the 1990 viral gastroenteritis outbreak from oysters. Proc. $2^{\text {nd }}$ Int. Conf. on Shellfish Depuration. Rennes, France, 1992, April, pp. 31-36.

15. Boxman I. L., Tilburg J. J., Te Loeke N. A., Vennema H., Jonker K., de Boer E., Koopmans M. Detection of noroviruses in shellfish in the Netherlands. Intern. J. Food Microbiol, 2006, vol. 108 (3), pp. 391-396.

16. Halliday M.L., Kang L. Y., Zhou T.K., Hu M.-D., Pan Q.-C., Fu T.-Y., Huang Y.S., Hu S. L. An epidemic of hepatitis A attributable to the ingestion of raw clams in Shanghai, China. J. Infect. Dis., 1991, vol. 164 (5), pp. 852-859.

17. Mele A., Stroffolini T., Palumbo F., Gallo G., Ragni P., Balocchini E., Tosti M., Corona R., Marzolini A., Moiraghi A. Incidence of and risk factor for hepatitis A in Italy: public health indications from a 10year surveillance. J. Hepatology, 1997, vol. 26, pp. 743-774.

18. Macaluso A., Petrinca A., Lanni L., Saccares S., Amiti S., Gabrieli R., Divizia M. Identification and sequence analysis of hepatitis A virus detected in market and environmental bivalve mollusks. J. Food Prot., 2006, vol. 69 (2), pp. 449-452.

19. Efimochkina N. R. Viral contaminants of food and methods of their detection. Hygiene and sanitation, 2017, vol. 96, no. 6, pp. 576-584. (In Russian)

20. Muniain-Mujika I., Calvo M., Lucena F., Girones R. Comparative analysis of viral pathogens and potential indicators in shellfish. J. Food Microbiol, 2003, vol. 83 (1), pp. 75-85.

21. Croci L., Ciccozzi M., De Medici D., Di Pasquale S., Fiore A., Mele A., Toti L. Inactivation of Hepatitis A virus in heat-treated mussels. J. Appl. Microbiol, 1999, no. 87, pp. 884-888.

22. Abad F. X., Pintó R. M., Gajardo R., Bosch A. Viruses in mussels: public health implications and depuration. J. Food Prot., 1997, no. 60, pp. 677-681.

23. Koff R.F., Sear H.S. Internal temperature of streamed clams. Medical Intelligence, 1967, no. 273, pp. 737-739.

24. Nechaev V. V., Mukomolov S. L., Romanova E. S. Enterovirus and non-enterovirus infections in tourists and migrants (travel medicine). Part 3: General characteristics. Polio. Rotavirus and norovirus infections. Viral hepatitis A and E. St. Petersburg, 2015. 92 p. (In Russian)

25. Shieh Y., Monroe S. S., Fankhauser R. L. Detection of norwalk-lake virus in shellfish implicated in illness. J. Infect. Dis., 2000, vol. 181, no. 2. pp. 360-366.

26. Cramer E. N., Blanton C. J., Blanton L.N. Epidemiology gastroenteritis on cruise ships, 2001-2004. Am. J. Prev. Med., 2006, vol. 30, no. 3, pp. 252-257.

Authors'information:

Stanislav A.Lopatin - MD, Professor; stanislavlopatin47@yandex.ru

ViktorV.Zakrevskii — MD, Assistant Professor; viktor.zakrevskii@szgmu.ru

Elena I. Yuvanen - PhD (Economics), Assistant Professor; yuvanen.elena@yandex.ru 